\title{
Effects of Negotiated Interaction on Mongolian-nationality EFL Learners' Spoken Output
}

\author{
Xueping Li \\ School of Foreign Languages, Inner Mongolia University for the Nationalities \\ Huolinhe Street, Tongliao City, Inner Mongolia, P. R. China \\ Tel: 86-475-8313174Ｅ-mail: 1xpfsu@163.com
}

Received: February 17, 2012

Accepted: March 5, 2012

Published: June 1, 2012

doi:10.5539/elt.v5n6p119

URL: http://dx.doi.org/10.5539/elt.v5n6p119

\begin{abstract}
The present study examines the effect of negotiated interaction on Mongolian-nationality EFL learners' spoken production, focusing on the teacher-learner interaction in a story-telling task. The study supports the hypothesis that interaction plays a facilitating role in language development for learners. Quantitative analysis shows that Mongolian learners gained significant improvement on language accuracy and fluency. The interaction offered occasions for phonological, syntactical as well as semantic language development for individual learners. However, how far these occasions may serve as a facilitating tool for language development depended on the learners' response in the interaction and their uptake in subsequent language production. The analysis also shows that Mongolian learners drew their attention to meaning prior to language forms in dealing with input and output. Their performance was not so much determined by their present language proficiency level, but rather by their L1 background (Mongolian), L2 (Chinese) and negotiation types they engaged in.
\end{abstract}

Keywords: Negotiation, Interaction, Output, Uptake

\section{Introduction}

According to Swain $(1985,1995)$, language acquisition may result from language production, or output, spoken output being one of them. While Gass (2003: 234) has mentioned, interactional structure in conversation has been one of the focuses in second language acquisition (SLA) research since 1980s, when researchers began to notice the function of interaction "not only as a medium of practice, but also the means by which learning takes place". Conversational interaction contains several factors beneficial for ESL/EFL learners, including reception of comprehensible input and interactional feedback (Long, 1983b; Gass \& Varonis, 1994) and "pushed" modifications in language production (Swain, 1995, 2000, 2005), thus fulfilling the capacity of interaction to connect both input and output (Pica, 1994b, 2005; Gass, 2003; Gass et al., 2006).

While such studies in the West flourished, researchers in China have also made some attempts for oral English development, but without paying equal attention to the important role of interaction (Wang \& Zhou, 2004). Besides, EFL learners of minority-nationality call for attention. As the national curriculum requires, English is a compulsory course for secondary education. However, they do not learn English until they come to senior high schools, even until to colleges. According to my teaching experience in one university in Inner Mongolia, those English majors of Mongolian nationality nearly have no English learning experience (no more than learning of the 26 letters) before they come to the university. English is a subject in their entrance examination but the grade is just a reference and not obligatory. That's one of the reasons for the poor recognition of English teaching in some minority areas. So they start from scratch when they are enrolled in the university. Mongolian as their first language, Chinese as their second language, they learn English as a foreign language. Because of the late starting point, a sense of inferiority compels them to speak either Mongolian or Chinese for communication after class, rather than practicing English (Li, 2003; Han, 2003). Furthermore, considering their English level, in most cases teachers of Han or Mongolian nationality are chosen for their oral lessons rather than foreign teachers. Therefore, they have little chance to experience real-life communication with native speakers. Although they gain considerable confidence in English tests after intensive training of one or two years (for example, they get quite high marks in grammar tests), they fail to appropriately apply the language in their speaking discourse. And as most English learners do in China, those learners are accustomed to relying on the teacher as source of information as well as authority in the classroom, and the teacher also takes responsibility of initiating talk most of the time. Therefore, chances are that the learners gain more opportunities to interact with the teacher for more guidance in learning. Hereby, the present study is motivated 
by the growing number of researches that have explored how learners can be pushed to produce more comprehensible and appropriate target language output by way of interaction (Gass \& Varonis, 1994; Lyster \& Ranta, 1997; Mackey \& Philp, 1998; Mackey, 2006; Ma, 2002; Zhang, 2009; Lin, 2009). The present study is intended to find out effects of teacher-learner interaction on spoken output of Mongolian English majors, with an aim to figure out how to engage both teachers and learners in effective interaction for effective oral English competence, thus providing some pedagogical implications for EFL minority learners.

The present study is intended to answer the following research questions:

a. Does conversational interaction between the Mongolian native-speaker students and the Chinese EFL teacher yield better target language (English) production by the students?

b. If yes, what possible effects does the negotiated interaction have on students' target language production?

\section{Literature Review}

\subsection{Theoretical Framework}

Input Hypothesis was put forward by Krashen (1985: 2): when the input that contains structures ("1") that are a bit beyond the learner's current level of competence $(i)$, they would progress in a predicable order and acquire the language structure naturally. Based on this, two corollaries were further put forward by Krashen. One point is that "speech cannot be taught directly but 'emerges' on its own as a result of building competence via comprehensible input" and speaking itself results in acquisition (1985: 2); the other states that sufficient comprehensible input that students receive guarantees necessary grammar, which is automatically provided and reviewed by the students.

Swain (2005: 471) summarized the Output Hypothesis "the act of producing language (speaking or writing) constitutes ... part of the process of second language learning". The output plays several roles in SLA (Swain, 1995, 2000, 2005): 1) The noticing/triggering function: language production may draw second learners' conscious attention to their linguistic problems; 2) The hypothesis-testing function: to produce language is a course that tests their hypothesis about linguistic forms; 3) The reflective function: language use is a way of reflecting others' or self-produced output, thus mediating second language learning.

Long's Interaction Hypothesis (1996: 451-452) maintains that “...Negotiation work that triggers interactional adjustments..., facilitates acquisition because it connects input, particularly selective attention, and output in productive ways" The Interaction Hypothesis combines both input and output, suggesting that receiving comprehensible input and interactional feedback (Pica, 1994b; Long, 1996), pushed modifications in output (Swain, 1995, 2000, 2005; Swain \& Lapkin, 1998), and negotiation for meaning (Gass, 2003) are all beneficial in SLA.

\subsection{Research on Interaction and Language Output in Foreign Countries and China}

More evidence can be found in many empirical studies for the linking role of interaction (Long, 1983b; Krashen, 1985; Ellis, 1994; Mackey, 1999; Gass, 2003; Mackey, 2006; Wang \& Carolyn, 2010).

For example, Gass \& Varonis (1994) confirmed the hypothesis that both prior interaction and prior input modification yield better L2 production. Swain and Lapkin (1998) conducted a study focusing on how interaction in collaborative tasks promotes L2 learning. The result confirmed dialogue as an enactment of mental processes and occasions for L2 learning, but the possible influence of their L1 on the L2 development and the pattern of interaction also call for further investigation. Mackey (1999)'s study revealed a positive relationship between conversational interaction and language output. This time, the level of learner involvement was taken into consideration: active engagement resulted in language output with more developmentally advanced structures.

Braidi (1995) reviewed several interaction studies and concluded that they reveal the nature of NS-NNS/NNS-NNS interaction, and focused on characteristics of interaction relevant to grammatical development, and brought out many recommendations for further study on interaction such as whether the structure of negotiated interaction enhances the accessibility of particular structures for the learner. Additional research focused on specific effects of interaction on L2 production (Mackey \& Philp, 1998; Philp, 2003) For example, Nobuyoshi and Ellis (1993) highlighted the retention that "pushed output" by interaction may have on learners' language development. Their findings made it clear that "pushing" output through interaction has delayed effects on learners' future language acquisition, and a long-term effect will arise if learners are pushed to produce more comprehensible output.

The studies mentioned previously are focusing on the interaction between language learners. In comparison, Musumeci (1996) probed into the effects of interaction in teacher-learner negotiation. Surprisingly, negotiation that led to modified output did not occur in this content-based setting, which does not echo the positive effects of interaction. Musumeci attributed it to the small sample size (three teachers and 48 learners), the teachers' sensitivity to affective variables in L2 learning, power relations between teachers and learners, and some time management 
considerations in the classroom. So the study challenges the feasibility of promoting more negotiation in content-based instruction. From the same perspective, Van den Branden (1997) conducted a quasi-experimental study by comparing peer-peer and teacher-pupil interactions. The results indicated that negotiations had significant delayed effects on learners' output. Most importantly, the learners in peer interaction paid much more attention to organization of content negotiation, while in teacher-pupil interaction the pupil benefited a lot from the opportunity that generated interactional modified output, but there was no specific measurement of interaction effects.

The latest studies are more concerned with different types of interactional feedback and take learners' responses into consideration for better understanding of the role of interaction (Lyster, 2004; McDonough \& Mackey, 2006).

In China, Zhang (2000) reveals the role of cognitive mechanism in L2 learning: it deals with the input of the learner accepts and puts it into declarative knowledge, which becomes procedural knowledge after repeated practice. This process greatly influences language output, which corresponds to what learners did in interaction in foreign research work, thus leading to relevant empirical studies in China (Sun \& Wang, 2003; Zhou, 2005; etc). For example, Zhang and Wu (2001) asked 12 freshmen of English majors to tell stories and do the same task one semester later. By quantitative analysis, they found that during the process of oral ability development, learners tended to pursue language fluency, complexity and consistency of content at the expense of language accuracy, which resulted in no improvement in accuracy in the second retelling. With the same data, Zhang (2000) made a close qualitative analysis. This time the results indicated the learners improved their language accuracy in the second retelling, which was contrary to the quantitative study. The researcher contributed this inconsistency to the insensitive accuracy items used in the quantitative analysis. Therefore, the combination of qualitative and quantitative analysis is more reliable and valid in guaranteeing the credibility of experimental results. Besides, the above empirical studies have focused on the language output after a long time of learning, while some factors that may influence the oral English developmental process are ignored, such as assistance from the peers and teachers, the ways they practice for improvement, and other classroom environments. Wu $(1996,1997)$ mentioned that the interaction between the teacher and the learners in the classroom is one of the essential factors in determining learners' development of oral ability. Zhang (2000) also hypothesized that learners may perform better in language output if under the interaction with their peers or teachers, which leaves room for further research in this field in Chinese context.

From an interactive view, Ma (2002) conducted a study, intending to find out learners' reaction to error-correction made by their peers and testify the role that group work plays in language learning. The results showed that group work provided more opportunities for learners to use target language and pay more attention to their speech errors. There is no analysis showing to what extent learners get positive effect from their peers' error-correction and self-correction, and it is not clear in what aspects learners get improved in their oral English by way of interaction.

According to the reference at hand, studies conducted by foreign scholars have touched upon more about learner-learner or NS/NNS interaction in a bilingual learning situation and less investigation on teacher-learner interaction comparatively, especially NNS/NNS teacher-learner interaction. The capacity of interaction to effectively connect both input and output still needs further verification. While studies in China have attached great importance to the role of language input and output, but still lack a combination of both qualitative and quantitative analysis on the cognitive process of oral English (Wang \& Zhou, 2004). The role of interaction in facilitating language development has not been fully explored (Wang, 2005; Wen, 2006). Besides, SLA studies in China were mainly conducted with the participation of EFL learners of Han nationality, little is known about the oral English performance of EFL minority learners. Still, studies concerning oral English development of EFL minority learners (Li, 2003; Wu, 2003; Han, 2003) call for more empirical evidence. The current study draws attention on how negotiated interaction deals with input and output, what are its effects on Mongolian learners' spoken output, what are those salient aspects of interaction that may influence learners' language and how much learners may benefit from the interaction, with an aim to figure out characteristics of Mongolian learners' oral production ability.

\section{Methodology}

\subsection{Research Design}

A pretest/posttest design was adopted: the learners were required to retell a story according a reading material twice individually, first immediately before the interaction with the teacher, second immediately afterwards. So the study consisted of:

1. Pretest: individually retelling a story.

2. Interaction: retelling the same story to his teacher of their oral lesson.

3. Posttest: individually retelling the same story. 


\subsection{Experiment Implementation}

\subsubsection{Participants}

One intact class of 50 junior English majors of Mongolian nationality in a comprehensive university in Inner Mongolia was selected. 29 (27 females and 2 males) participants were chosen representing the intermediate proficiency level of the whole class, with reference to their CET-4 marks. Their oral lesson teacher (Chinese, female, who has more than 15 years of teaching experience) interacted with the learners in the storytelling task. Another Chinese teacher (female) responsible for the oral lesson of another Mongolian class, and I myself, assisted in recording the learners' first and second retelling separately.

\subsubsection{Task}

Activity that may promote interaction and elicit language production gains priority, a storytelling task was thus applied. Learners were required to complete the storytelling task based on three narratives (including stories Legend of Chinese Valentine's Day, Why You Should be Careful When Making Promises? and The Magic Pear). The suggestion from a foreign teacher and two Chinese teachers (including the oral English teacher of the intact class) was the main reference for choosing materials since they have oral English teaching experience in Mongolian classes. The stories were chosen from folk tales on English learning websites with word range between $400-500$ for each one. Some adaptations were made according to consultation with the two Chinese teachers as well as the information gained from the pilot study with 5 Mongolian learners, including Chinese annotation of some words and simplification of some complex sentences (with the first story as an example in Appendix G). This ensured better comprehensibility and flexibility of language elicitation. The three narratives indicated an average readability $83.52 \%$ done by "Text Readme (2.0)", ensuring that the materials were of equal difficulty in accordance with the participants' proficiency level.

\subsubsection{Implementation}

Storytelling was one of the participants' regular classroom activities. They were told beforehand that their performance would be used for research purposes. They were informed of completing the task as they usually did in the oral class, but the second monologue would be marked by the teacher as part of their final grade, in order to ensure that the participants. These instructions aimed at a seamless integration of the retelling task into regular classroom teaching so that the students would work towards their final achievement of the course but not my experiment.

For the task, one participant chose one of the three predetermined reading materials. After 5 minutes' reading without permission to take notes, the participant began his first retelling (4-5 minutes) to the researcher who listened without any comment. And then he was asked to come into another classroom and retell the same story with their teacher. This time the teacher, being familiar with the materials beforehand, had an interaction (5-7 minutes) with the participant and made sure the participant had recounted the story clearly enough. After the interaction, another teacher was waiting for the participant to retell the same story (4-5 minutes) and just marked without any interruption. Other participants did the same one after another.

Shortly after the research, a short interview (half an hour) was conducted with the teacher about her understanding on the participants' performance during the interaction and her evaluation on this kind of interaction. Another interview (20 minutes) with randomly assigned 5 participants was made concerning such questions as difficulties in retelling, some support or help they wanted from the teacher-learner interaction, etc., along with their opinion about the task and interaction. All the information was written down as notes.

\subsection{Data}

\subsubsection{Qualitative Data Collection}

All the storytelling and the interaction were audio taped. Among the 29 participants, a female student did not finish the first retelling because of nervousness, so altogether 28 valid data were obtained, from which eight participants' (named Ao, Bao, Ma, Qing, Liu, Er, Wen and Ba) recordings were transcribed by the researcher and double-checked. They were selected according to the typicality principle (their active performance in interacting with the teacher) for depth analysis. Overall the recordings lasting 100 minutes and 11 seconds were used for data analysis, including the two retellings lasting 33.35 and 25.26 minutes separately as well as the interaction lasting 43 minutes and 10 seconds. Besides, the information collected from the two interviews was taken as reference for later discussion.

\subsubsection{Data Preparation}

Accuracy and fluency were selected as dependent variables as for the quality of the participants' storytelling (Skehan \& Foster, 1999; Robinson, 2001). 
Accuracy was measured by counting the number of error-free T-units as a percentage of the total number of the T-units in the two retellings of any one session (One session for each participant consists of two sections: one is the first and second retelling, the other is one teacher-learner interaction). A T-unit was defined by Chaudron (1988) as any syntactic main clause and its associated subordinate clauses. The following was taken as an error-free T-unit.

One day, a, the beggar entered a market, er, hoping for, hoping for getting a pear.

(Wen; Section 2)

Fluency was measured by calculating the number of repetitions (immediate and verbatim repetition of a word or phrase) (Skehan \& Foster, 1999) such as

I sew, sewed, sewed the heaven because...

(Qing; Section 2)

false starts (utterances that are abandoned before completion) (Skehan \& Foster, 1999) such as

So the man, em, began, en, so the man became silent and went away. $\quad$ (Qing; Section 2)

as well as pauses such as "er", "en" (Zhou, 2004).

The negotiations in the interaction were categorized as the following (Mackey et al., 2000) to show the specific effects that the conversational interaction had on language output (Abbreviated as PE, ME, LE and SE):

(1) Phonological episode

$\mathrm{S}$ : then, en, the man went away. The next man is the, is a, a herdsman. He said, er, er, "my, my father, er, have a whip (mispronounced as [waip]).

T: whip, whip.

S: whip (correct pronunciation).

(Qing)

(2) Morph-syntactic episode

$\mathrm{S}$ : Yesterday, en, it wa..., it was rai..., ra..., rain.

T: It rained.

S: It rained.

(3) Lexical episode

$\mathrm{S}$ : As soon as, er, there was a grow, er, grow a, a ...

T: Bud?

S: a bud. And the bud grows very fast and, and...

(4) Semantic episode

S: And the bud grows very fast and, and...

$\mathrm{T}$ : and then (pause)

$\mathrm{S}$ : and, and then the bud grows er, two feet tall.

$\mathrm{T}$ : Two feet?

S: er.

T: Three feet.

S: Oh, three feet.

(Ao)

\subsubsection{Data Analysis}

First, qualitative data from the learners' pre and posttest performance was quantified according to the coding scheme mentioned above. Secondly, with language accuracy and fluency as variables, the main analysis-Wilcoxon Singed Ranks Test done by SPSS (10.0) was used to compare learners' performance prior and after the teacher-learner interaction, to see if there were statistically significant differences in the two retellings. And then, four negotiation types were identified in each interaction and accordingly separate frequency was measured as percentage of the total number of negotiations in the 8 interactions. Meanwhile, successful and unsuccessful uptake of the negotiations was also measured with reference to the learners' posttest performance. The negotiation episodes and corresponding uptake were discussed for qualitative analysis of the research findings. Three EFL teachers of Mongolian-nationality helped to go through the qualitative data, and joined the discussion on possible reasons that account for Mongolian learners' oral English performance. 


\section{Results and Discussion}

\subsection{The Interpretation of the Results}

As for the research question 1, language accuracy and fluency are used for judgment. Compared with their first individual storytelling, all the eight learners improved significantly as a result of teacher-learner interaction. Generally, the result of the study is consistent with what have been done on the effect of interaction in the literature (Pica, 1991; Pica et al., 1996; Musumeci, 1996; Van den Branden, 1997; Lyster \& Ranta, 1998; etc.).

\subsubsection{Accuracy}

Table 1 (In Appendix A) shows that in the pretest, the error-free T-unit scored $38.65 \%$ averagely, while in the posttest, the mean ran to $50.42 \%$. The data shows significance at 0.05 level $(\mathrm{p}=0.012<0.05)$. In other words, all the participants performed significantly better in the second retelling in producing accurate clauses. However, the fact that standard deviation in the posttest (.1781) was greater than the pretest (.1349) indicates that there were greater disparities among individuals in accuracy development in the second retelling, with $4.49 \%$ and $14.13 \%$ running the bottom and top line of the improvement (See Table 2 in Appendix A).

\subsubsection{Fluency}

For language fluency, all the participants gained significant improvement after the teacher-learner interaction (See Table 3 in Appendix A).

The pauses in the retellings averagely reduced from 46.6250 to 30.5000 , suggesting that obviously the learners spent less time in planning their language output $(\mathrm{p}=0.012<0.05)$ after they had gained more understanding of the story in the teacher-learner interaction. Simple repetitions reduced sharply from 27.5000 to 14.3750 in the second retelling, which was significant at 0.05 level $(\mathrm{p}=0.012<0.05)$, indicating that after the interaction, all the participants needed less time to think how to organize their language. The reduction of standard deviation shows more consistent language performance for all the participants in terms of pause changes and simple repetitions in the posttest. As for false starts, significant reduction (from 13.3750 to $10.8750, \mathrm{p}=0.011<0.05$ ) also shows that all the participants had clearer thinking process and more fluent language use as a result of more familiarity with the content through the interaction. The standard deviation after the interaction (4.9982) was greater than the first retelling (4.7189), indicating that there were uneven distributions of improvement among individual learners (See Table 4 in Appendix A).

The data reveals that the most obvious change was the sharp decrease of pauses in the posttest. False starts reduced accordingly, although not so evident as the changes of pauses and simple repetitions.

\subsubsection{Possible Effects that Negotiated Interaction Has on Learners' Output}

As for research question 2, like many other studies (Gass \& Varonis, 1994; Swain \& Lapkin, 1998; Mackey \& Philp, 1998; Mackey, 1999; Philp, 2003; McDonough \& Mackey, 2006; Ma, 2002), the study has also shown that the interaction offered occasions for semantic, syntactical as well as phonological language development for the individual learner. The new finding of the current research, however, is that how far these occasions may serve as facilitating tool for language development depended on the learners' response to the interactional feedback and their uptake in subsequent language production. (See Table 5 in Appendix A)

Overall there were 82 negotiation episodes (see randomly selected transcriptions in Appendix C-F) in the interaction. As the data shows, semantic negotiation (Appendix C) was dominant (49\%), with phonological episodes (Appendix F) occurring least frequently (8\%). Moreover, the Mongolian learners successfully took up most of what they had negotiated with the teacher in their later language production, with uptake more likely occurring in episodes involving phonological recasts and negotiation of meaning.

\subsection{Discussion}

\subsubsection{Qualitative Analysis on the Effects of Interaction}

There were a lot of opportunities for language development in the interaction.

Firstly, among the negotiation episodes, the rate of meaning negotiation found in this study was higher than Ellis et al. (2001) reported. In their study a great majority of negotiation involved form rather than meaning in communicative activities. Though the current study was just confined to a storytelling task, the large number of meaning negotiation indicates that the Mongolian learners' allocation of attention resource on meaning had precedence over forms while dealing with the input and language production. For example, Ma at first did not know why the King gave the third man a bucket of gold instead of his throne. The teacher found the inconsistency in her storytelling and initiated relevant questions to test her comprehensibility. 
(1) T: Yeah, so whether he would like to give his throne to ... the man?

S: (interrupt in ...) No! No! No!

T: or a bucket of gold?

S: A bucket of gold? En, I think the king don't want to give his throne to the man, bu..., but at last he gave the..., the third man a bucket of gold.

The teacher found that the learner was still at a loss about the issue, she went on to modify the content of the story for clearer idea.

(2) T: If, if the man admitted he's telling the truth,

S: Yeah,

T: so he has to give (pause)

S: the third man a bucket of gold.

T: Yeah, a bucket of gold. Right?

S: O!

(Ma)

It seemed that the learner had got the point by uttering "O!", but later the learner again raised the question: "But why he did give the man a bucket, bucket of gold?" (SE 3). The teacher tried to negotiate the point again with the learner, and with "O, yeah, I, I re..., I understand" (SE 3), Learner Ma got herself through and expressed herself correctly in the second retelling. In this way, interaction "results in making the message understandable and the input more accessible to the learner" (Musumeci, 1996: 287).

Sometimes, when the learner was unable to divide the speech-stream into known words and structures, or to map semantics onto unknown syntactic structure, the teacher adopted the "pedagogical" strategies, e.g., raising questions by modifying the input, providing the learner with greater opportunity to draw on their own resources and experiment with new forms about the target language. For example,

(3) T: Do you think he wants to eat the pear?

S: No.

T: No? Why didn't he eat the pear? Why didn't he eat the pear?

S: En, in the story, he didn't eat a pear. En, he dig a hole and put it into the hole. And it grows a tall tree of pe..., a pear (correct pronunciation).

T: Because he wanted to share (pause)

S: share a swee..., a habit,

T: the pears with (pause)

S: (simultaneously) the pears with others.

$\mathrm{T}$ : Yes, who needs the pears. Right?

S: Yes.

(Wen)

The learner just gave a very short summary about the story, so the teacher wanted to elicit more language production for better task accomplishment. More questions about details "pushed" the learner to rethink what she read and express her thought with more language production. When the learner did not succeed in coming up with a proper response, the teacher suggested a possible solution to direct him for better understanding of the story and language output. In this way, the interaction acts as a link between comprehensible input and pushed output. Therefore, the interaction has facilitated language use, which constructs linguistic knowledge and contributes to language learning (Swain, 2000). Thus, based on better comprehension of the story in these negotiations, the Mongolian learners' attention resources switched to discourse appropriateness in later performance, which was reflected in their significant improvement in language fluency (See Table 4.3, 4.4). The findings reinforce what Gass et al. (2006) have found that when the interaction involves negotiation for meaning, it facilitates SLA. Since focused negotiation may lead learners' attention resources to particular "discrepancies" between their interlanguage and the target language, it represents a stage for language learning and development for oral competence (Gass, 2003).

Secondly, the interaction also contributes to morph-syntactical modifications of the learners' language. When one learner said, "Then the beggar picked up, er, the pears and gave it all the ...", the teacher noticed the inappropriateness of the language and reminded the learner, interrupting with "gave them to ", waiting for the 
learner to go on. The learner noticed the feedback and continued as "gave them to all the people in the, er, fruit shop" (ME 1). Later, the learner modified her language according to what the teacher directed. $71 \%$ of such episodes were successfully retained and directly contributed to more accurate sentence construction in their posttest performance.

In the interview, the teacher involved in the interaction mentioned that in such oral tasks, Mongolian learners usually tend to focus on language fluency at the expense of language accuracy. So in her teaching, she often offers timely but not frequent modifications of their sentence construction and finds that it works well in helping them to build self-monitoring awareness on their own language in target language output.

Thirdly, occasions for lexical improvement were generated in the negotiations during which some problems were detected and corrected by the teacher, such as "a police" for "a policeman" (LE 2), misuse of "he" or "she"(LE 3, 4), etc. Sometimes, the teacher provided word choice for them to go on with the retelling. For example:

(4) S: En, then, en, the tailor, leav..., left the room silence.

T: silently.

S: silently. En, (clear her throat), en.

Apparently the teacher was clear about what the learner expressed and directed her to appropriate language production by providing the correct word use. The learner followed the teacher's guidance and took up the word in her later storytelling. The teacher's highlight on the word choice promoted the learner's noticing of her inappropriate expression. The result reinforces the claims made by Gass \& Varonis (1994): in producing target language, the learners' attention drawn to their problematic utterances will enhance them to notice the gap between what they want to say and what they have said, so learners will modify the language output accordingly with the help drawn from their interlocutor. In other words, this is one of the effects of negotiations that may "serve to focus learner's attention on potentially troublesome parts of their discourse, providing them with information that can open the door to IL modification", and these modification may result in subsequent language change (Gass et al., 1998: 301).

Fourthly, the phonological improvement was equally evident since $86 \%$ recasts of pronunciation were realized in the learners' second retelling, with the pronunciation correction of "pear" being typical (see PE 1,3,4). It is needed to mention that in Mongolian phonetics, there is no such corresponding diphthong like pear in English, but with the diphthong like beer in English (Wu, 2003). Ellis et al. (2001) stated that attention as selection is assumed to be firstly drawn to specific stimuli. When the learners heard the correct pronunciation which has no counterpart in their L1, they were impressed by the marked feature of the target language and managed to take up the correction after several turn-takings of talk with the teacher.

So far, the analysis provides more evidence of how interaction promotes language development. And these findings suggest that negotiation generated in the interaction may lead to better retention of what have been negotiated. Apparently, the Mongolian learners benefited much from the negotiation retention.

\subsubsection{Inferences on EFL Mongolian Learners' Ability of Spoken Output}

According to their performance in the study, it is found that the cognitive input processing as well as language transfer account much for the Mongolian learners' oral production ability.

In the teacher-learner interaction, all the learners tended to focus on conveying meaning to the teacher, allocating comparatively less attention on morph-syntactic arrangement. This is evidenced in their more uptake of meaning negotiation (80\%) and less uptake in morph-syntactic negotiation (71\%). The learners' own focuses and decisions may confine the extent to which those occasions for language development may play a facilitating role. According to the interpretation of the five participants in the interview, they had similar experience: in oral English expression, their main purpose is to make others understand what they are trying to convey. One of the participants named Er said that he knew he would make some grammatical mistakes in spoken English, but the most important thing was to make the main points of the story clear to the teacher. Attention on grammar would hinder his flow of thought, thus influencing language fluency. That is to say, sometimes they will be aware of the inappropriate expression in terms of grammar, but make no modifications since primarily they have to figure out what they are going to express for next content point. Therefore, they seldom make self-correction in speaking English, including those grammatical mistakes identified in the retellings and interaction in this study. Occasional self-corrections for example, on past tense use in the two retellings, resulted from interactional feedback of the teacher. This finding partly corresponds what Wang (2002) found on oral production ability of English majors of Han nationality: the participants (50\%) in his study would make sense judgment on how to convey messages, but without thinking of the appropriateness of grammatical construction. The five participants also mentioned that things would be different in writing in English. They would take both grammar and meaning into consideration. That's one of the reasons why their oral English competence does not parallel with their present proficiency level reflected in their CET-4 grade. 
Language transfer is another important influence. In a trilingual situation, Mongolian learners grow up with their L1-Mongolian, with Chinese accompanying them later in some social communications. When they start learning English in colleges, both L1 and L2 interfere. The difference of tense-aspect system between Mongolian and English poses some difficulty (Han, 2003). Mongolian has similar tense-aspect system like English but is more complicated. Qian (2005) provided empirical evidence to show that the difference has impact on Mongolian learners' English acquisition: Mongolian is rich in aspect. Present tense marker $y$-a/ge expresses an action that starts in the past and is continuing into the present. Progressive -ju/jü+bai is the equivalent of English progressive (2005: 64). The continuous -ysayar/gseger bai refers to action that happened and continuous up to a certain selected point of time. It often appears with stative verbs like live, think and dynamic verbs like come from, wait for, etc. and it can occur with any type of verbs except part of Achievements (e.g., notice, recognize). The scope of -ysayar/gseger bai is larger than the English progressive, let alone plus $y$-a/ge and -ju/jü+bai. Mongolian learners are faced with the task of narrowing down the scope of the -ysayar/gseger bai because in L2 input they cannot find a form that embodies the functions of -ysayar/gseger bai.

Thus, Mongolian transfer is reflected in more use of perfective and progressive markings, as well as overuse of progressive markings. Mongolian learners may overextend progressive markings to States. Occurrences of progressive states such as feeling in Learner Wen's two retellings as well as interaction (the policeman feeling sorry for the beggar) may be attributed to L1 transfer, since verbs like feel often appear with continuous -ysayar/gseger bai in their native language.

Apart from L1 (Mongolian) transfer, there is also L2 (Chinese) transfer. There are such sentences like the following:

(1) The beggar, en, very hungry.

那 乞正,... 非常 饿.

(2) The policeman confused.

$$
\text { 那个 警察 困惑了. }
$$

(3) He very angry.

他 非常 生气.

In Mongolian language, words with feelings imbedded such as anger, confusion are verbs and are not used with link verbs as Chinese. But suffixes to these verbs are necessary in this structure. So it may be concluded that these sentences were constructed directly from the Chinese sentence order (Wang, 2006). Such L2 (Chinese) transfer happens as a result of special learning situation that Mongolian learners engage in. On one hand, teachers of Han nationality are responsible for their oral lessons. The teacher explains language difficulties in Chinese and when the learners have difficulty in learning they have to speak Chinese and ask for help from the teachers and peers of Han nationality. Even teachers of Mongolian nationality teach with Chinese and English for most of the time. They speak Mongolian only when learners have special difficulties in understanding some language points. On the other hand, their textbooks are printed in English with Chinese as reference, the same as learners of Han nationality have. The participants in the interview mentioned that at the beginning, they had some difficulty in switching from classes of high schools with both Mongolian and Chinese in the courses, to English lessons of colleges only with Chinese prevalent, especially when they were facing the challenge of learning a third language. Now it is the fifth semester, so they have been accustomed to discussing with the teacher in Chinese and they tend to think Chinese rather than Mongolian when they deal with the English input. Hereby, in the interview, with the question on how they managed to get an outline of the reading text for retelling preparation, one participant named Ma said that first she tried to translate it into Chinese for the main idea within the settled time, and then tried to express the idea according to what she remembered in Chinese. Two of the interviewees (Bao and Wen) shared the same cognitive process. The other two (Er and $\mathrm{Ba}$ ) explained that usually they remembered some main verbs in the sentences and organized their language according to these verbs. When they encountered some words that were not familiar to them, they remembered the Chinese explanation in the brackets. So in the data, we have some negotiation episodes in which Chinese words popped out (see SE 1, PE 2). In other words, English-Chinese-English switching happens in Mongolian learners' cognitive process of subsequent oral production, which is similar to most Chinese learners do found by Wang (2002).

As for the individual differences in language improvement after the interaction, it depends on the teacher's focus and the learners' own decisions. In some cases, there was a lack of lexical negotiation in the interaction. Among the eight learners, there were three cases in which only one lexical episode occurred. The participants named Ma and Wen encountered some comprehension problems, so for most of the time they initiated questions about their confusion when negotiating with the teacher. Therefore, meaning as priority occupied much of the time. When it 
comes to the case of Er, he had less difficulty in comprehension, but with more morph-syntactic problems in his language, so the teacher's attention was drawn away to correct the wrong tense use and word collocations. Apart from that, it is also found that sometimes, despite the teacher's help, the learners' response to the interactional feedback and their own decisions in choices may confine their oral improvement to a small range. For example, the teacher provided some words for the learners to express their thinking better, such as "sympathetic" for the meaning of "sorry" in one interaction (Bao; LE 1). The learner noticed they were synonyms, and repeated the pronunciation several times, but in the later retelling, he still used "sorry". One possible explanation is what has been verified by McDonough and Mackey (2006: 698): immediate responses in the form of repetition might be simple imitations that do not indicate developmental progression. Another possible reason comes from their learning characteristics. It seemed that the learner felt safe using those words familiar to him, and was unwilling to try new language items to some extent. Possibly it is the common fear of difficulty in English learning imposes them to do so, with the lower "jumping-off point" in English learning compared with the other students of Han nationality in the same grade (Li, 2003).

To sum up, the present study provides more empirical evidence that what the learners experienced in the teacher-learner interaction pushed them to produce not only comprehensible, more complete and accurate output on the information level, which corresponds to the results in Van den Branden (1997)'s study, but also more morph-syntactically correct target language. Besides, Ohta (2000) considers the learner "as speaker/hearer who is involved in developmental processes which are realized in interaction" (2000: 51), while the present study not only takes the role of speaker/hearer into consideration, the learners are also considered as processors of input and producers of output. Interaction has proved an effective link between language input and output for the Mongolian learner in their developmental process of oral production.

\section{Conclusion and Implication}

The significance of the study lies in its primarily attempting exploration of EFL Mongolian-nationality learners' cognitive process as well as language characteristics in oral English development. It enriches SLA studies in China concerning English learning of minority students with empirical evidence. Meanwhile, there are some implications for teaching practice of EFL Mongolian learners: language output by way of tasks involving interaction can be a good choice to facilitate language competence within limited practice periods for Mongolian learners in the trilingual situation. Both teachers and learners should refine their attitudes, roles and responsibilities in instructional process, and interpret interactional negotiations as "an important component of the learning experience" (Musumeci, 1996: 321). Just as teachers may need to adjust their behaviors to minimize their omniscient roles in the classroom, learners need to make attempts in initiating and modifying their utterances, in spite of any embarrassment or frustration that such efforts may provoke in the interaction; Swain (1985) noted that each learner brings to the classroom his or her own store of knowledge, opinion and experience, which are the most powerful resources for teachers to explore learners' potentially productive language. As in the case of Mongolian learners indicated in the study, they have their special thinking ways. Familiarity and detailed analysis on their language characteristics by way of various classroom interactions, therefore, may assist teachers in figuring out more appropriate ways to promote their language development. Consequently, since both Mongolian and Chinese transfer pose some difficulties for English learning as shown in the study, English teaching for Mongolian learners should be reinforced by minimizing negative transfer.

\section{References}

Braidi, S. M. (1995). Reconsidering the Role of Interaction and Input in Second Language Acquisition. Language Learning, 45, 141-175. http://dx.doi.org/10.1111/j.1467-1770.1995.tb00965.x

Chaudron, C. (1988). Second Language Classrooms: Research on Teaching and Learning. Cambridge: Cambridge University Press.

Ellis, R. (1994). The Study of Second Language Acquisition. Oxford: Oxford University Press.

Ellis, R., Helen Basturkmen, \& Shawn Loewen. (2001). Learner Uptake in Communicative ESL Lessons. Language Learning, 51(2), 281-318. http://dx.doi.org/10.1111/1467-9922.00156

Gass S., \& E. Varonis (1994). Input, Interaction, and Second Language Production. Studies in Second Language Acquisition, 16, 283-302. http://dx.doi.org/10.1017/S0272263100013097

Gass, S., A. Mackey, \& L. Ross-Feldman. (2005). Task-Based Interactions in Classroom and Laboratory Settings. Language Learning, 55(4), 576-611. http://dx.doi.org/10.1111/j.0023-8333.2005.00318.x

Gass, S. M. (2003). Input and Interaction. In Catherine J. Doughty \& Michael. H. Long (Eds.), The Handbook of Second Language Acquisition (pp. 224-255). London: Longman. 
Han, Bo. (2003). On the Significance of Language Comparison and Tense Expression of Mongolian and English. Journal of Inner Mongolia University for Nationalities, 29(5), 67-70.

Kang, Zhifeng, \& Lu, Xiaoyong. (1998). The Present Situation, Problems and Countermeasures of Oral English Teaching in China. Foreign Languages and Teaching, 9, 32-35.

Krashen, S. D. (1985). The Input Hypothesis: Issues and Implications. London: Longman.

Li, Yuelin. (2003). Study on the Particularity of EFL Learners of Ethnic Minorities. Journal of Southwest University for Nationalities, 24(8), 334-336.

Lin, Qiong. (2009). A Review on Interaction Teaching in Foreign Countries. Journal of Tianjin Foreign Studies University, 3, 63-70.

Long, M. H. (1983b). Native Speaker/non-native Speaker Conversation and the Negotiation of Comprehensible Input. Applied Linguistics, 4, 126-141. http://dx.doi.org/10.1093/applin/4.2.126

Long, M. H. (1996). The Role of the Linguistic Environment in Second Language Acquisition. In William C. Ritchie \& Tej K. Bhatia (Eds.), Handbook of Second Language Acquisition (pp. 413-454). San Deigo: Academic Press.

Lyster, R., \& L. Ranta. (1997). Corrective Feedback and Learner Uptake: Negotiation of Form in Communicative Classrooms. Studies in Second Language Acquisition, 19, 37-66.

Lyster, R. (2004). Differential Effects of Prompts and Recasts in Form-focused Instruction. Studies in Second Language Acquisition, 26, 399-432. http://dx.doi.org/10.1017/S0272263104263021

Ma, Dongmei. (2002). The Learners' Self Error Correction After Group Work in English Teaching. Journal of Foreign Language Teaching and Research, 34(2), 131-135.

Mackey, A., \& J. Philp. (1998). Conversational Interaction and Second Language Development: Recasts, Responses, and Red Herrings? Modern Language Journal, 82, 338-356. http://dx.doi.org/10.1111/j.1540-4781.1998.tb01211.x

Mackey, A. (1999). Input, Interaction and Second Language Development. Studies in Second Language Acquisition, 21, 557-587. http://dx.doi.org/10.1017/S0272263199004027

Mackey, A. (2006). Feedback, Noticing and Second Language Development: An Empirical Study of L2 Classroom Interaction. Applied Linguistics, 27, 405-430. http://dx.doi.org/10.1093/applin/ami051

McDonough, K., \& A. Mackey (2006). Responses to Recasts: Repetitions, Primed Production, and Linguistic Development. Language Learning, 56(4), 693-720. http://dx.doi.org/10.1111/j.1467-9922.2006.00393.x

Musumeci, D. (1996). Teacher-learner Negotiation in Content-based Instruction: Communication at Cross-purposes? Applied Linguistics, 17, 286-325. http://dx.doi.org/10.1093/applin/17.3.286

Nobuyoshi, J., \& R. Ellis. (1993). Focused Communication Tasks and Second Language Acquisition. English Language Teaching Journal, 47, 203-210. http://dx.doi.org/10.1093/elt/47.3.203

Ohta, Amy Snyder. (2000). Rethinking Interaction in SLA: Developmentally Appropriate Assistance in the Zone of Proximal Development and the Acquisition of L2 Grammar. In James P. Lantolf (Ed.), Sociocultural Theory and Second Language Learning (pp. 51-78). Oxford: Oxford University Press.

Philp, J. (2003). Constraints on "Noticing the gap": Non-native Speakers' Noticing of Recasts in NS-NNS Interaction. Studies in Second Language Acquisition, 25, 99-26.

Pica T., Lincoln-Porter F., Paninos D., \& Linnell J. (1996). Language Learners' Interaction: How Does It Address the Input, Output, and Feedback Needs of L2 Learners? TESOL Quarterly, 30, 59-84. http://dx.doi.org/10.2307/3587607

Pica, T. (1991). Classroom interaction, Participation, and Negotiation: Redefining Relationships. System, 19, 437-452. http://dx.doi.org/10.1016/0346-251X(91)90024-J

Pica, T. (1994b). Research on Negotiation: What Does It Reveal About Second Language Learning Conditions, Processes, and Outcomes? Language Learning, 44, 493-527. http://dx.doi.org/10.1111/j.1467-1770.1994.tb01115.x

Pica, T. (2005). Classroom Learning, Teaching, and Research: A Task-Based Perspective. The Modern Language Journal, 89, 339-352. http://dx.doi.org/10.1111/j.1540-4781.2005.00309.x

Qian, Cuijing. (2005). The Roles of Lexical Aspect and L1 Transfer in the Acquisition of Tense-Aspect Morphology. MA Thesis. Beijing: Beijing Foreign Studies University.

Skehan, P., \& P. Foster (1999). The Influence of Task Structure and Processing Conditions on Narrative Retelling. 
Language Learning, 49(1), 93-120. http://dx.doi.org/10.1111/1467-9922.00071

Sun Yan, \& Wang, Dawei. (2003). Effects of Input and Output on Oral English Development-A Comparative Study of Two Teaching Results. Foreign Language World, 3, 31-35.

Swain, M., \& Sharon Lapkin. (1995). Problems in Output and the Cognitive Process They Generate: A Step Towards Second Language Learning. Applied Linguistics, 16, 371-391. http://dx.doi.org/10.1093/applin/16.3.371

Swain, M., \& Sharon Lapkin. (1998). Interaction and Second Language Learning: Two Adolescent French Immersion Students Working Together. The Modern Language Journal, 82(3), 320-337. http://dx.doi.org/10.1111/j.1540-4781.1998.tb01209.x

Swain, M. (1985). Communicative Competence: Some Roles of Comprehensible Input and Comprehensible Output in Its Development. In S. Gass \& C. Madden (Eds.), Input in Second Language Acquisition (pp. 235-253). Rowley, Mass: Newbury House.

Swain, M. (1995). Three Functions of Output in Second Language Learning. In G. Cook \& B. Seidlhofer (Eds.), Principle and Practice in Applied Linguistics: Studies in Honor of H. G. Widdowson (pp. 125-144). Oxford: Oxford University Press.

Swain, M. (2000). The Output Hypothesis and Beyond: Mediating Acquisition through Collaborative Dialogue. In James P. Lantolf (Ed.), Sociocultural Theory and Second Language Learning (pp. 97-114). Oxford: Oxford University Press.

Swain, M. (2005). The Output Hypothesis: Theory and Research. In E. Hinkel (Ed.), Handbook of Research in Second Language Teaching and Learning (pp. 471-484). Mahwah, NJ: Erlbaum.

Van den Branden, K. (1997). Effects of Negotiation on Language Learners' Output. Language Learning, 47(4), 589-636. http://dx.doi.org/10.1111/0023-8333.00023

Wang, Gayan. (2005). The Process of Language Production: A Cognitive Psychology Perspective. Foreign Language Teaching, 26(2), 6-10.

Wang, Lifei, \& Zhou, Dandan. (2004). 12 Years of Oral English Research in China: Review and Current Situation. Foreign Language World, 4, 7-14.

Wang, Lifei. (2002). A Qualitative Study on Oral English Competence of Chinese College Students-The Expression Process and Communicative Strategies. Journal of Beijing International Studies University, 5, 50-55.

Wang, Qiaoying, \& Carolyn D. Castro (2010). Classroom Interaction and Language Output. English Language Teaching, 3, 175-186.

Wang, Ying. (2006). The Oral English Error Analysis of Chinese Students. Journal of Shaanxi Normal University, 3, 390-394.

Wen, Qiufang. (2006). The Trend and Characteristics in Oral English Vocabulary of English Majors. Foreign Language Teaching and Research, 38 (3), 189-195.

Wu, Xudong. (1996). A Theoretical Model of Oral Development in Foreign Language Teaching Circumstances (a). Modern Foreign Languages, 4, 20-23.

Wu, Xudong. (1997). A Theoretical Model of Oral Development in Foreign Language Teaching Circumstances (b). Modern Foreign Languages, 1, 49-52.

Wu, Yunna. (2003). Comparison of English and Mongolian Pronunciation and the Teaching Application. Journal of Inner Mongolia Normal University, 16(1), 51-53.

Zhang, Shumei. (2009). The Role of Input, Interaction and Output in the Development of Oral Fluency. English Language Teaching, 2, 91-100.

Zhang, Wenzhong, \& Wu, Xudong. (2001). A Quantitative Study on Oral Fluency of Second Language. Modern Foreign Languages, 24(4), 342-351.

Zhang, Wenzhong. (2000). A Qualitative Study on Oral Fluency of Second Language. Modern Foreign Languages, 23(3), 273-283.

Zhou, Dandan. (2004). Effects of Practice Frequency on Storytelling Task. Journal of PLA University of Foreign Languages, 27(5), 41-45.

Zhou, Weijing. (2005). Effects of Language Input Modes on Oral English Output. Journal of PLA University of Foreign Languages, 28(6), 53-58. 


\section{Appendix A. Results}

Table 1. Descriptive statistics of accuracy

\begin{tabular}{|l|c|c|c|c|c|}
\hline & $\mathbf{N}$ & Mean & Std. Deviation & Asymp. Sig. (2-tailed) & \\
\hline ACCUR1 & 8 & .3865 & .1349 & $.012 *$ & \\
\cline { 1 - 4 } ACCUR2 & 8 & .5042 & .1781 & & \\
\hline
\end{tabular}

Note:* indicates statistical significance at 0.05 level.

Table 2. Individual performance on accuracy

\begin{tabular}{|ll|l|l|l|}
\hline \multicolumn{2}{|l|}{ Participants } & Pretest & Posttest & Improvement \\
\hline 1 & Ao & $28.57 \%$ & $38.24 \%$ & $9.67 \%$ \\
\hline 2 & Bao & $60.87 \%$ & $75 \%$ & $14.13 \%$ \\
\hline 3 & Ma & $45.83 \%$ & $52.38 \%$ & $6.55 \%$ \\
\hline 4 & Qing & $25.81 \%$ & $30.30 \%$ & $4.49 \%$ \\
\hline 5 & Liu & $28.57 \%$ & $36.36 \%$ & $7.79 \%$ \\
\hline 6 & Er & $45 \%$ & $55.56 \%$ & $10.56 \%$ \\
\hline 7 & Wen & $27.27 \%$ & $36.36 \%$ & $9.09 \%$ \\
\hline 8 & $\mathrm{Ba}$ & $50 \%$ & $56.52 \%$ & $6.52 \%$ \\
\hline
\end{tabular}

Table 3. Descriptive statistics of fluency

\begin{tabular}{|c|c|c|c|c|c|}
\hline & N & Mean & Std. Deviation & Asymp.Sig.(2-tailed) & \\
\hline PAUSE1 & 8 & 46.6250 & 22.6649 & $.012 *$ & \\
PAUSE2 & 8 & 30.5000 & 20.2414 & $.012 *$ & \\
\hline REPE1 & 8 & 27.5000 & 22.4627 & & \\
REPE2 & 8 & 14.3750 & 11.7466 & $.011 *$ & \\
\hline FSTART1 & 8 & 13.3750 & 4.7189 & & \\
FSTART2 & 8 & 10.8750 & 4.9982 & & \\
\hline
\end{tabular}

Note: * indicates statistical significance at 0.05 level.

Table 4. Individual performance on fluency

\begin{tabular}{|ll|l|l|l|l|l|l|}
\hline \multirow{2}{*}{\begin{tabular}{c} 
Participants \\
\cline { 2 - 7 }
\end{tabular}} & \multicolumn{2}{|c|}{ Pause } & \multicolumn{2}{c|}{ Simple repetition } & \multicolumn{2}{c|}{ False start } \\
\cline { 2 - 7 } & Pretest & Posttest & Pretest & Posttest & Pretest & Posttest \\
\hline 2 & 60 & 22 & 34 & 11 & 15 & 12 \\
\hline 3 & Bao & 84 & 70 & 36 & 21 & 17 & 16 \\
\hline 4 & Qing & 56 & 37 & 17 & 12 & 19 & 17 \\
\hline 5 & Liu & 43 & 33 & 20 & 7 & 17 & 14 \\
\hline 6 & Er & 51 & 18 & 8 & 2 & 6 & 3 \\
\hline 7 & Wen & 10 & 8 & 5 & 4 & 7 & 5 \\
\hline 8 & Ba & 23 & 12 & 76 & 38 & 13 & 9 \\
\hline
\end{tabular}


Table 5. Negotiation episodes and corresponding uptake

\begin{tabular}{|l|c|l|l|}
\hline Negotiation episode & Frequency of negotiation & \multicolumn{2}{|c|}{ Frequency of uptake } \\
\cline { 3 - 4 } & & Successful & Unsuccessful \\
\hline Phonological & $7(8 \%)$ & $6(86 \%)$ & $1(14 \%)$ \\
\hline Lexical & $18(22 \%)$ & $12(67 \%)$ & $6(33 \%)$ \\
\hline Semantic & $40(49 \%)$ & $32(80 \%)$ & $8(20 \%)$ \\
\hline Morph syntactic & $17(21 \%)$ & $12(71 \%)$ & $5(29 \%)$ \\
\hline Total & $82(100 \%)$ & $62(76 \%)$ & $20(24 \%)$ \\
\hline
\end{tabular}

Appendix B. Transcription Conventions

\begin{tabular}{|l|l|}
\hline Symbol & Meaning \\
\hline S & Student \\
\hline T & Teacher \\
\hline ( ) & Transcriber's description \\
\hline, & Micro pause \\
\hline$\ldots$ & Pause before completion \\
\hline$[$ ] & Phonetic representation \\
\hline Words in Bold & Emphasis by the learner or the teacher \\
\hline
\end{tabular}

(Adapted from Ellis et al. 2001)

\section{Appendix C. Semantic Episode}

\section{Episode 1}

1. S: En, the empress, er, impressed and decided to, er, let, er, the empress let them, er, meet each other once a year. En, it, er, 应该说正是七月七号, 能那样说吗?

2. T: Yes, right. July, the seventh.

3. S: En, en, en,

4. T: From then (pause)

5. S: en..., er, the seventh day of July became, en, the Chinese Valentine's Day.

Episode 2

1. S: Er, en, er, later, er, when the sho..., when the pear,

2. T: the pears were gone (pause)

3. S: Yeah, when the pears were, were, were gone, er, a merchant, pear merchant, pear merchant go

back his shop, she found all his pear (mispronounced as []), pears disappeared. En, maybe now she, she know what had happened. (Liu)

Episode 3

1. S: But at first the king said he would want to give his throne to the, to a man.

2. T: Yes.

3. S: But why he did give the man a bucket, bucket of gold? (laugh)

4. T: Yeah, because the man was lying.

5. S: yes.

6. T: that, said the king borrowed a bucket of gold from him.

7. S: (simultaneously) borrowed a bucket of gold from him. Yes.

8. T: And the king wouldn't admit that he, he's telling the man, he's telling a lie that make a sitting, sitting man stand up and a wa..., a sleeping man wake up. Right?

9. S: (simultaneously) a sleeping man wake up. Yes.

10. T: so if he, he, he admit that the man had told him a lie, 
11. S: O.

12. T: So he would rather give the man a bucket of gold, right?

13. S: (simultaneously) gold. O, yeah, I, I re..., I understand.

\section{Appendix D. Morph-syntactic Episode}

\section{Episode 1}

1. S: Then the beggar picked up er, the pears and gave it all the

2. T: gave them to (pause)

3. S: gave them to all the people in the, er, fruit shop. ... and, (clear her throat). A lot of people very pleasure.

4. T: Yeah.

(Ao)

Episode 2

1. S: En, he, en (clear her throat), en, his, en, he announced, who en, who who can en (clear her throat), who can, en, make a man, en, from, en, from, en, sitting to stand, to, stand up and en, from sleeping, en, to woke up.

2. T: Wake up.

3. S: Wa..., wake up, sleeping to wake up. En.

4. T: Yeah.

(Bao)

Episode 3

1. S: Then the beggar shared the pears to the around people.

2. T: Yeah, with the people around.

3. S: Yes, with around people, en, included the shop assistant.

\section{Appendix E. Lexical Episode}

\section{Episode 1}

1. S: The policeman felt very s..., felt very sorry for, for the beggar.

2. T: Sympathetic. Sympathetic.

3. S: sym..., symp...,

4. T: sympathetic.

5. S: sympathetic.

6. T: Yeah.

7. S: sympathetic.

(Ba; no uptake)

Episode 2

1. $\mathrm{S}$ : En, a later, a police came in.

2. T: A policeman.

3. S: A policeman came in.

Episode 3

1. S: Er, the beggar very happy and she, when she got the pear, she dig, she dig a hole in the pear.

2. T: Yeah, maybe the beggar is a man? He?

3. S: Yes.

(Liu; no uptake)

Episode 4

1. S: En, maybe now she, she know what had happened.

2. T: Yeah. He

3. S: He, he maybe what had happened. 


\section{Appendix F. Phonological Episode}

\section{Episode 1}

1. S: er, en, if I can, er, dig a hole in the, er, if, if I can bury the pear (mispronounced as ), bury the pear (mispronounced) in,

2. T: Pear.

3. S: Pear (mispronounced).

4. T: Pear, pear.

5. S: Pear (correct pronunciation).

6. T: Yeah.

Episode 2

1. S: En, he had, so he had, en, he had sewed (mispronounced as saved) heaven by...

2. T: Yeah, sewed. You mean sewed.

3. S: Oh, sewed heaven by... 䖝子?

4. T: Yeah, louse.

5. S: Louse.

Episode 3

1. T: OK. Maybe how do you pronounce “梨”?

2. S: pear (mispronunciation).

3. T: pear, pear (pronunciation correction).

4. S: Pear (correct pronunciation). Yeah.

Episode 4

1. S: because, the pear (mispronunciation) becames a magic tree of pear (mispronunciation).

2. T: Pears (correct pronunciation).

3. S: Pears (correct pronunciation). Yes, thanks. (laugh)

Appendix G. Reading Materials

\section{The Magic Pear}

A beggar entered a market, holding out his hand and hoping for a coin or two. The shoppers and merchants ignored (忽视) him as he passed. He stopped in front of the pear merchant's cart. "Please sir, you have so many pears. Can you spare just one? I haven’t eaten for seven days.” The pear merchant, alarmed and angered, tried to chase (赶 走)the beggar away by calling him names and threatening (威胁) to beat him. The local policeman came by. Feeling sorry for e beggar, the policeman bought a pear and gave it to the beggar. The beggar thanked the policeman, shook his hand, and started to dig a hole. Confused, the policeman asked the beggar if he was going to eat the pear.

“Oh, no, sir. You've given me a magic pear. I'm going to bury it and it will grow into a huge tree," replied the beggar as he continued to dig his hole. The people in the market gathered around and watched the beggar bury the fruit. When the last handful of dirt was placed back in the hole, the beggar sat down and chanted (唱圣歌). The eyes of the crowded widened as soon as the beggar sat down, a tiny green bud (嫩芽) sprang from the dirt, climbing up and up, thicker and stronger. When the bud reached three feet tall, it grew branches. On those branches, leaves filled the void. And at the end of each branch, many pears sprouted. There were so many of them that the beggar had to stand up and pick the fruit, or else the tree would collapse (倒下). The beggar, with pears in his arms, started to give away his pears. "I have so many pears and I want to share with everyone who doesn't have any." When all the pears were gone and eaten, the beggar took a long knife from his bag and cut down the magical pear tree. Everyone thanked the beggar for sharing, including the pear merchant. The beggar smiled and walked away. As soon as the crowd died down, the pear merchant walked back to his cart. To his surprise, all of his pears were gone. The beggar had given them all away. The pear merchant's cart had a handle missing. The beggar had cut it off. The pear merchant sat down on his empty, broken cart and cried. 